\title{
Reading Mary Stuart's Casket Sonnets: Reception, Authorship, and Early Modern Women's Writing
}

\author{
Rosalind Smith
}

\begin{abstract}
The reception history of the casket sonnets attributed to Mary Queen of Scots is a rich archive of material, revealing the complex ways in which histories of reading intersect with the early modern woman writer's relationship to the institutions of authorship. By tracing the reception of these sonnets over four centuries, I argue that competing religious, historical, and geopolitical formations work to privilege or occlude Mary Stuart's authorship at different historical moments. Understanding these formations and their relationships to authorship and gender allows a new perspective on the canonical biases still at work in the field of early modern women's writing.
\end{abstract}

The Chicago edition of Elizabeth I's CollectedWorks, published in 2000, marks a moment in canon formation in early modern women's writing. ${ }^{1}$ Just as George Puttenham characterized Elizabeth's poem 'The doubt of future foes' as exemplary of the figure of the gorgeous - that rhetorical figure of speech 'the most bewtifull and gorgious of all others' - so the size, comprehensiveness, and prestige of the Chicago edition positions Elizabeth as literary exemplar within the twenty-first-century field of early modern women's writing. Yet as Puttenham argues in The Arte of English Poesie, Elizabeth's 'ditty most sweet and sententious' was written in response to the politically threatening 'secret practizes' of her cousin, Mary Queen of Scots. ${ }^{2}$ Elizabeth's textual pre-eminence is grounded upon the discredited and volatile presence of her sovereign cousin. The writing of Mary Queen of Scots, as generically varied and rhetorically complex as that of her cousin, has no place in Puttenham's panegyric to Elizabeth's rhetorical skill; as a consequence, she exists solely as a historical character associated with disorder and danger. This binary positing Elizabeth as writer par excellence and Mary Stuart as silent foil - is sustained within current accounts of female sovereign authorship in the field of early modern women's writing. There is no scholarly edition of Mary

\footnotetext{
${ }^{1}$ Leah S. Marcus, Janel Mueller, and Mary Beth Rose, eds, Elizabeth I: Collected Works (Chicago: University of Chicago Press, 2000).

${ }^{2}$ George Puttenham, The Arte of English Poesie (1589), p. 207. Place of publication of all early works is London, unless otherwise stated.
} 
Stuart's writing, prose, or poetry, and only a handful of critical articles and book chapters attending to her work. ${ }^{3}$ Despite the focus of much recent scholarship on expanding the boundaries of the field of early modern women's writing to include different modes of publication and models of authorship, Mary Stuart's works, mostly circulated in manuscript, have largely remained unread.

There is one exception, however: the casket sonnets. These poems were widely circulated in print from 1571, and although they have received relatively little recent critical attention, they have been read and commented upon in a wide range of circumstances for four centuries. ${ }^{4}$ This article traces the specific reception history of these sonnets in order to understand how practices of reading and redaction have informed perceptions of Mary Stuart's authorship. In this case study of the reception of the casket sonnet sequence, its shifting critical status is historicized, with surprising results. In the sixteenth and eighteenth centuries, key texts and approaches produced Mary Stuart's obscurity as an author, while at other historical moments her poetry was revived as conforming to models of femininity that have since become unfashionable. The relationship of early modern women writers to institutions of authorship is, I would suggest, closely linked to histories of reading that can be difficult to recover and to assess. Yet the difficulty of recovering these histories does not mean that their absence should be assumed: as Paul Salzman notes, 'there has been a tendency to project forgetfulness' onto histories of reception in the field of early modern women's writing. ${ }^{5}$ Attending to such reading histories where they are available clarifies the extent to which our existing models of early modern women's authorship are shaped by the reception and redaction of their texts.

\section{I}

Unlike much early modern women's writing, the casket sonnets have a sustained reception history that can be followed from their first circulation in manuscript to current accounts of Mary Stuart's reign. As scholarship on

${ }^{3}$ For recent critical considerations of Mary Queen of Scots's writing, see Sarah M. Dunnigan, Eros and Poetry at the Courts of Mary Queen of Scots and James VI (Basingstoke: Palgrave Macmillan, 2002); Lisa Hopkins, Writing Renaissance Queens: Texts by and about Elizabeth I and Mary Queen of Scots (Newark: University of Delaware Press, 2007); Peter J. Herman, Royal Poetrie: Monarchic Verse and the Political Imaginary of Early Modern England (Ithaca, NY: Cornell University Press, 2010).

${ }^{4}$ A Scots translation of sonnet sequence was published in George Buchanan, Ane Detectioun of the duinges of Marie Quene of Scottes, trans. Thomas Wilson (1571), sigs. Q4 ${ }^{r}-\mathrm{S} 1^{\mathrm{r}}$.

${ }^{5}$ Paul Salzman, Reading Early Modern Women's Writing (Oxford: Oxford University Press, 2006), p. 219. 
the reception of the historical figure of Mary Queen of Scots shows, it is a rich and various history, but one focused on Mary Stuart as icon rather than author. ${ }^{6}$ The casket sonnets were believed to have been discovered - by the Scottish lords seeking to depose Mary from her throne - in a small silver and gilt coffer in June 1567, along with eight letters written by Mary to her lover the Earl of Bothwell and two marriage contracts. ${ }^{7}$ The casket materials, including the sonnets, were used by her enemies as evidence that Mary was complicit both in the murder of her second husband and in her subsequent marriage. The Catholic queen's Protestant political enemies justified the removal of their sovereign precisely because of her status as suspected murderer, motivated by her love for Bothwell into jeopardizing her claim to the throne, and unlawfully plotting to establish him as king.

The casket sonnets' role in establishing this case is clear. They describe the anonymous female speaker's passion for her adulterous lover in vividly material terms, detailing her rape, her rivalry with his wife, and her desire to prove the intensity of her love. ${ }^{8}$ Having described in the first sestet of the opening sonnet that her lover is 'alredy in possessioun | Of my bodie, of hart, that refusis no payne' $(5-6),{ }^{9}$ in the second sonnet the speaker details

${ }^{6}$ See Jayne Elizabeth Lewis, Mary Queen of Scots: Romance and Nation (London: Routledge, 1998); Alexander S. Wilkinson, Mary Queen of Scots and French Public Opinion (Basingstoke: Palgrave, 2004); and John D. Staines, The Tragic Histories of Mary Queen of Scots, 1560 1690 (Aldershot: Ashgate, 2009).

${ }^{7}$ In the February of 1567 (a watershed year for Mary), the Queen's unhappy marriage to her second husband, Lord Darnley, ended with his murder when his Edinburgh lodgings were blown to rubble by igniting a cache of gunpowder in the cellar. A group of Scottish lords including the Earl of Bothwell were suspected of the crime, as was the Queen herself. Bothwell was tried and acquitted of the murder, then abducted the Queen, held her captive in Dunbar castle and was rumoured to have raped her. He then annulled his marriage to Jean Gordon and married the Queen at Holyrood Palace on the 15 May. Rival Scottish lords in the court joined forces to depose Bothwell and his new wife, arguing that the death of Darnley was the first step in a plot devised by Mary and Bothwell to instate the Earl on the Scottish throne. The casket sonnets were key evidentiary texts in this process.

${ }^{8}$ The ninth sonnet in the sequence begins 'For him also I powred out many tearis, | First quhen he made himself possessor of thys body. I Of the quhilk then he had nat the hart' (Buchanan, Ane Detectioun, sigs. Q4 ${ }^{\mathrm{r}}-\mathrm{S} 1^{\mathrm{r}}$, Il. 113-15). From this account of sexual possession without emotional investment it is assumed that the speaker was raped. However, this is complicated if the speaker is assumed to be Mary Queen of Scots and the lover Bothwell, as any charge of rape would have been legally invalidated by the fact of their marriage, as marriage as well as pregnancy were viewed in the sixteenth century as indications of women's consent and were often means of settling rape charges prior to judgement. See Barbara J. Baines, 'Effacing Rape in Early Modern Representation', English Literary History, 65 (1998), 69-98.

${ }^{9}$ Buchanan, Ane Detectioun, sigs. Q4 ${ }^{r}-\mathrm{S} 1^{\mathrm{r}}$. Line references within this signature range are quoted in text. 
precisely what it means for a queen to abandon political responsibility for love:

In his handis and in his full power,

I put my sonne, my honour, and my lyif,

My contry, my subiects, my soule al subdewit,

To him, and has none vther will (15-18).

This is a powerful and unambiguous abdication of a sovereign's duty to care for and protect her subjects in return for their allegiance, played out here across related personal, familial, and public spheres. The sonnet's emphasis on the personal experience of erotic love is expanded throughout the sequence. The opening two sonnets are followed by four that deal with the speaker's rival, the beloved's existing wife, who is represented as in every way unworthy of his love, and then by five remaining sonnets and a concluding sestain that give 'sic profe' (such proof) (25) of the speaker's more legitimate passion. Identified as the confessions of a queen by the phrase 'my subiects', the poems deliver the fictional Mary Stuart's motive for the murder of her husband Lord Darnley: a love that 'increaseth' to the point that she 'haif forsaken all kin and frendes | And set aside all vther respectes' (124-25).

The sequence sits uneasily within traditions of aristocratic sixteenthcentury women's writing, its engagement with popular forms and its scandalous content at odds with the devotional and political writings of many of Mary Stuart's contemporaries, not to mention her own polished verse. Its vivid mix of heightened emotion and the material details of everyday life, used to pursue a case for the sovereign speaker's erotic self-justification in the face of convention, draws as much from traditions of popular complaint as from the genre of the sonnet sequence. ${ }^{10}$ Yet the casket sonnets were very widely circulated, both in manuscript and print, as the authentic voice of the Scottish queen. As John Guy argues, the casket materials became central to William Cecil's case against Mary, which was assembled in the interests of Elizabeth I. Cecil amended the minutes of the 1568 tribunal at which the

${ }^{10}$ For accounts of complaint see John Kerrigan, Motives of Woe: Shakespeare and 'Female Complaint' (Oxford: Clarendon Press, 1990); Götz Schmitz, The Fall of Women in Early English Narrative Verse (Cambridge: Cambridge University Press, 1990); and Lawrence Manley, Literature and Culture in Early Modern London (Cambridge: Cambridge University Press, 1995). On the elements of complaint within this sequence, see Rosalind Smith, "'Plaintes full of dissimulation": The Casket Sonnets, Female Complaint and True Crime', in Expanding the Canon of Early ModernWomen'sWriting, ed. Paul Salzman (Newcastle upon Tyne: Cambridge Scholars, 2010), pp. 125-42. 
Scottish lords first produced the casket and its contents to specify that they were written with 'the Queen of Scots' own hand'. ${ }^{11}$

The sonnets were later circulated in print in the vernacular translations by Thomas Wilson of a Latin collection of writings by George Buchanan, De Maria Scotorum Regina, which was first published in $1571 .{ }^{12}$ Wilson's translations were also published in 1571 and printed in London, La Rochelle, and St Andrews as Ane Detectioun of the Duinges of Marie Quene of Scottes. ${ }^{13}$ Ane Detectioun is an assemblage of multiple documents, beginning with two prose tracts by Buchanan, a narration, and a forensic oration, alongside other material related to the case against Bothwell and Mary. It concludes by printing the sonnets in both French and what Cathy Shrank has described as 'a pseudoScottish voice, easily comprehensible to an English reader, but marked with selected Scottishisms'. ${ }^{14}$ In this way, the casket sonnets are framed by their first editor, Buchanan, as one of multiple pieces of evidence for Mary Stuart's complicity in a marriage plot that involved the murder of her first husband. It is in this form that they reach their widest audience.

The discovery and circulation of the sonnets in these multiple redactions mark the casket materials as early modern true crime texts, centred upon the lived experience of crime. Not only were the sonnets first read in manuscript as evidence for Mary Stuart's motive in murdering her first husband Darnley, they are also carefully introduced in Buchanan's Detectioun as evidence for forensic interpretation by the lay reader in print. ${ }^{15}$ The circumstances of Mary Stuart's adulterous love for Bothwell and her complicity in murdering her husband have parallels in other true crime publications in the period. In both the 1573 case of Mistress Anne Saunders and the 1591 case of Eulalia Page, adultery led to each woman devising a plot to murder her husband in collusion with her lover and others. Like the events surrounding Mary Stuart's remarriage, these cases generated multiple, competing textual accounts in the popular press as pamphlets, ballads, and even plays. ${ }^{16}$ However, the highly

${ }^{11}$ John Guy, 'My Heart is My Own': The Life of Mary Queen of Scots (London: Fourth Estate, 2004), p. 432.

${ }^{12}$ George Buchanan, De Maria Scotorum Regina totaque eius contra Regnum coniuratione (1571).

${ }^{13}$ See n. 4, above.

${ }^{14}$ Cathy Shrank, 'Manuscript, Authenticity and "evident proofs" against the Scottish Queen', in Tudor Manuscripts 1485-1603, ed. A. S. G. Edwards, British Library: English Manuscript Studies 1100-1700, 15 (Chicago: University of Chicago Press, 2010), pp. 198-218 (p. 203).

${ }^{15}$ See Lorna Hutson, The Invention of Suspicion: Law and Mimesis in Shakespeare and Renaissance Drama (Oxford: Oxford University Press, 2007), p. 237.

${ }^{16}$ London, British Library, MS Sloane 1896, Anon., 'The Wofull Lamentacion of Mistress

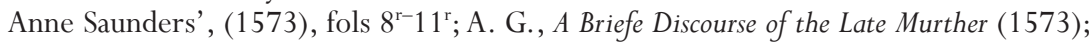


charged political context surrounding the widespread publication of the casket materials means that they have been read and commented upon for over four centuries. This context also shapes their particular reception history, which has been fixed upon questions of authenticity and the relationship of the sonnets to Mary Stuart's biography.

The immediate response to the circulation of the casket sonnets divided along religious and national lines. There is some response to their first circulation in manuscript: in a 1568 letter to Elizabeth, the Duke of Norfolk describes the sonnets as 'divers fonde ballades of her owne hand', which, together with the letters, 'do discover suche inordinate love betwene her and Bothaill, her loothsomnes and abhorringe of her husband that was murdered, in suche sorte, as every good and godlie man cannot but detest and abhorre the same' ${ }^{17}$ Norfolk's emphasis that the sonnets are 'of her owne hand' marks their authenticity in a way not automatically attributable to letters, transcribed by secretaries and written in cipher, and his reading of the poems, the first recorded, is wholly in terms of the attribution of bad character to Mary Queen of Scots. As Lorna Hutson has recently argued, early modern drama deployed the inferential construction of character, using partial information in a forensic manner to give the reader a sense of 'the substantial, psychic reality of the conjectural reconstruction of the past', a sense of what a character is really feeling or who that character really is. ${ }^{18}$ Although Hutson's interest is in dramatic mimesis, her research into the intersection of legal and literary narrative structures has a wider reach, extending her argument for mimetic reading as a way of inventing character to other literary forms. ${ }^{19}$ In a legal context, forensic rhetoric used inference to argue for cause of action as much through the nature of an act as through the character of the actor. Evidence was seen to be open to manipulation in the process of making a persuasive

Anon., A Warning for Fair Women (1599); Anon., A true discourse of a cruel and inhumaine murder, committed vpon M. Padge of Plymouth (1591); Anon., Sundry strange and inhumaine Murthers, lately committed (1591); Thomas Deloney, The Lamentation of Master Page's Wife (London, 1591); Anon., The Sorrowful complaint of Mistris Page (1591); Anon., The Lamentation of George Strangwidge (1591); Ben Jonson and Thomas Dekker, Page of Plymouth (1599), now lost. For a fuller account of these similarities, see Rosalind Smith, 'The Case of Mary Queen of Scots, Lord Darnley and Lord Bothwell: Initiating the Literature of Husband-Murder in Sixteenth-Century England', Notes and Queries, 59 (2012), 498-501.

${ }^{17}$ Norfolk, Sussex, and Sadleir to Elizabeth (6 October 1568), in Calendar of State Papers, Scotland:Volume 2: 1563-69, ed. Joseph Bain (Edinburgh, 1900), pp. 513-44 (p. 537). Available online at <http://www.british-history.ac.uk/report.aspx?compid=44186> [accessed: 28 September 2011].

${ }^{18}$ Hutson, Invention of Suspicion, p. 226 (emphasis in original).

${ }^{19}$ Hutson, pp. $206-08$.

Parergon 29.2 (2012) 
case, establishing good or bad character in the mind of the jury. ${ }^{20}$ Norfolk here makes a case for the sonnets as establishing a love that is not only detestable and abhorrent to himself, but to 'every good and godlie man'; the poems are read as evidence of an excessive and aberrant passion - an 'inordinate love' - that not only attracts disapprobation but foregrounds the queen's bad character. The letters and ballads, in Norfolk's account of their first, secret disclosure by the Scottish lords, are seen to be sufficient to convince Elizabeth of Mary's complicity in 'the detestable crime of the murder of her husband'. He notes that if indeed they are in her own hand, this conclusion 'is verie hard to be avoyded'. ${ }^{21}$ It is an important early reading, because Norfolk's response indicates clearly the potential role in Elizabethan propaganda of these sonnets in fixing a new character to Mary Queen of Scots in the minds of good and godly men: a character whose erotic practices excite abhorrence and provide evidence for murder.

By far the most influential of Mary Stuart's sixteenth-century readers was her editor in print, George Buchanan. Buchanan's Ane Detectioun begins with his narratio of the events leading to the murder of Darnley and Mary's subsequent marriage to Lord Bothwell. He claims that this account is written for Elizabeth in response to the stories circulating about her cousin, 'quha allwa [who always] are for your part no less desirous to understand the truth, than we for ours to auoide sclaunder'. ${ }^{22}$ In his professed eagerness to 'knit up the mater as breefly as possibly may be', Buchanan weaves a narrative that twins Mary's disdain for her husband with her active pursuit of an affair with Bothwell $\left(\mathrm{A} 2^{\mathrm{r}}\right)$. His account, grounded in the material world of Edinburgh and its surrounds, has a comic and hyperbolic quality; he describes Bothwell being dragged into the queen's bed 'euen out of his wiues armes, halfe a sleepe, halfe naked' (B2v). Neither brief, nor wary of slander, Buchanan's introductory narrative provides a riveting introduction to Mary's complicity not only in adultery, but in the plot to murder Darnley and to have herself abducted by Bothwell, a 'maruelous fine inuention' devised to necessitate her hasty marriage $\left(F 2^{v}\right)$. As Buchanan states repeatedly, her letters are the evidence for this complicity: 'whether with hir will, or against his will, eueryman may easily perceiue by hir awin [own] letters that sche wrote to him by the way as sche was in hir iourney' $\left(F 2^{v}\right)$. All of the events that Buchanan describes in vivid detail in the first section of Ane Detectioun are 'by

${ }^{20}$ Erica Sheen and Lorna Hutson, 'Introduction: Renaissance, Law and Literature', in Literature, Politics and the Law in Renaissance England, eds Sheen and Hutson (Basingstoke: Palgrave Macmillan, 2005), pp. 1-22 (p. 8).

${ }^{21}$ Norfolk, Sussex, and Sadleir to Elizabeth (6 October 1568), in Calendar, ed. Bain, p. 537.

${ }^{22}$ Buchanan, Ane Detectioun, sig. A2 ${ }^{\mathrm{r}}$. Subsequent signature references will be cited in text. 
writings and witnesses sa prouaible', designed to 'stick sa fast emprintit in the knowledge of all the pepill' $\left(\mathrm{F}^{\mathrm{v}}{ }^{\mathrm{v}}\right.$ ).

As if this colourful chronological account of events were not enough to damage Mary's character, it is followed by a forensic oration, which approaches the narrative, comically outlined in the first account, more aggressively, providing underlying reasons and motivations for events and answering an imaginary, skeptical interlocutor. ${ }^{23}$ This section examines Mary's character in detail, providing an analysis that focuses on her specific fault of intemperance as a quality of certain women: 'they loue with excesse, and hait without measure, and to quhat side sa euer they bend, they are not gouerned by aduised reason, but carried by violent motion' (G1 v). Again, her own writings provide the best evidence of what the oration later describes, in an echo of Norfolk's response, as 'immoderate desire' which 'brast out from hir many times many words disclosing it' $\left(\mathrm{J} 3^{\mathrm{r}}\right)$. The writings that appear later in Ane Detectioun have been framed as synecdochically revealing 'hir selfe', a character of excess, intemperance, and inordinate love $\left(\mathrm{G} 1^{v}\right)$.

Before finally introducing the sonnets, however, Buchanan provides further authenticating material. He includes a memorandum detailing the discovery of the casket, a version of one of the marriage contracts found, and the indictment of Bothwell at his April 1567 trial in the assize court. Printed as both French originals and in the Anglicized Scots translation, the sonnets are offered as proof of the narrative Buchanan has built in his compendium of material. They can finally be examined by the reader as corroborating evidence, the point at which the detection ends, and Buchanan's case is closed. In the page following their reproduction, the text asks in a larger font: 'Now iudge Englishmen if it be gud to change Quenis' $\left(\mathrm{V}^{\mathrm{r}}\right)$. The sonnets carry the weight of evidence not only for condemnation of Mary as a character and as a queen, but as justification for English action against her: 'Quhile your Quenis enemy liueth, hir danger co[n]tinueth. Desperate necessities wyll dare the vttermost' $\left(\mathrm{V} 3^{\mathrm{r}}\right)$.

Reprinted six times during the sixteenth century, Buchanan's Ane Detectioun shapes subsequent anti-Marian readings of the sonnets. His account was balanced by a number of Catholic defences, the most significant of which was John Leslie's enormous and multiply reprinted $A$ Defence of the Honour of ... Marie Queene of Scotlande. ${ }^{24}$ First published in 1569, Leslie's Defence

${ }^{23}$ Staines, Tragic Histories, p. 38. Buchanan's authorship of the oration has been questioned on the basis of style and perceived inconsistencies with the opening detection.

${ }^{24}$ John Leslie, A Defence of the Honour of the Right Highe, Right Mightie and Noble Princesse, Marie Queene of Scotlande; and Dowager of France (1569). All subsequent folio references are to this edition and are given in the text. For an account of the complex publishing history of this first edition, see Kimberly Coles, "'Printed at London Anonymous”: Was there 
does not discuss the sonnets directly; he could not have anticipated their later importance to the policies of semi-publicity pursued by Elizabeth and William Cecil in circulating Ane Detectioun. ${ }^{25}$ However, he addresses the issue of the letters' authenticity in curiously ambivalent terms. Suggesting that 'it is in no case to be supposed or coniectured that suche a wise, virtuous Ladie would sende any such letters', he also speculates that if they were sent, because of their 'hasarding of her estimation and honour', they would not have 'remained undefaced'; in fact, he surmises that instructions would have been 'geven forthwith to burn them, and make them away' $\left(10^{v}\right)$. In an argument repeated in almost all subsequent defences, he also questions the material status of the documents - the lack of subscription, dates or nominated bearer - as well as noting that many in the court could 'counterfeit in their writings the Queenes very character' $\left(11^{\mathrm{r}}\right)$. While Leslie's immediate defence of the casket materials allows for the possibility that these letters might have been sent by Mary, they are consistently referred to as forgeries in the remainder of his defence; as 'shamefull vntrue texts', the whole an 'vnpleasant, iarring and untuneable plain song' of the Scottish lords' 'setting and making' $\left(13^{\mathrm{r}}\right)$. A very different character is constructed here for Mary Queen of Scots, one of virtue and passivity. Her decision to marry Bothwell, for example, derived from external pressures, the 'craftie, colluding seditious heads, and the necessitie of the time, as then to her seemed, did in a maner enforce her' $\left(16^{r}\right)$. The same acts and evidence recruited by Buchanan to her condemnation become for Leslie a marker of her feminine virtue, inscribed as a kind of weakness and openness to manipulation. Leslie's formulation is repeated in other Catholic defences of the period, such as Adam Blackwood's Martyre de Marie Stuart, which draws heavily on Leslie's text in its extended case for the forgery of the letters. ${ }^{26}$

Jayne Elizabeth Lewis suggests that the sustained dichotomy of good and bad character developed in these first responses to the casket material derives from the application of 'relatively little political theory' to Mary's demission of the crown. ${ }^{27} \mathrm{I}$ would like to suggest a more specific source for the construction of her character, in the traditions of inference at work in the early modern courts and mirrored in these early texts attacking and defending

Ever an Attempt to Publish the First Edition of the Defence of Mary Queen of Scots in England?', Review of English Studies, 49 (1998), 273-81.

${ }^{25}$ See James Emerson Phillips, Images of a Queen: Mary Stuart in Sixteenth-Century Literature (Berkeley: University of California Press, 1964), pp. 62-63.

${ }^{26}$ Adam Blackwood, Martyre de Marie Stuart Royne dEscosse et Douariere de France (1587; repr. Edinburgh, 1834), pp. 80-84.

${ }^{27}$ Jayne Elizabeth Lewis, 'Hamilton's “Abdication”, Boswell's Jacobitism and the Myth of Mary Queen of Scots’, English Literary History, 64 (1997), 1069-90 (p. 1074). 
her reign. These texts newly institute the reader as arbiter of her guilt or innocence through the assessment of textual evidence framed by forensic oration. They establish a pattern of reading, however, that is replicated in later accounts, some of which draw upon the sixteenth-century reception of her writing, in ways that reproduce their binaries of character but divorce them from their true crime origins.

\section{II}

The seventeenth-century reception of the writing of Mary Stuart is marked by diminishing interest in her literary status, marginalizing those of her poetic texts still in circulation. The pattern of her characterization according to extremes of virtue or vice that developed in the sixteenth century remains, although a different set of political issues is recruited to maintain the arguments for and against her character. At the beginning of the seventeenth century, vestiges of the sixteenth-century attack and defence of Mary's character continue in George Conaeus's Catholic defence of Mary in a Vita published in Latin in Rome, 1624, and in the reprinting without alteration of Buchanan's Detection in $1651 .{ }^{28}$ However, the production of texts concerning Mary Stuart lessens in the seventeenth century, and is marked by a change in emphasis prompted at first by a revisionist historical stance designed to attract the patronage of James I. In 1624, William Camden's The Historie of the Life and Death of Mary Stuart Queene of Scotland is dedicated to James I and claims its motivation from the wish of 'euery man to desire, and to be delighted with the relation and story of his own Ancestors and predecessors'.$^{29}$ The text omits the casket sonnets as it recuperates the positive presentation of Mary's character from earlier Catholic defences, as 'the fairest and goodliest Princesse of our time', whose political failures are attributed to the manipulations of others. This emphasis upon Mary's virtuous princeliness reflects favourably upon James I's qualifications and legitimacy as monarch, and this legitimacy is reinforced at the text's conclusion which cites his succession as fulfilling Mary's chief desire that the kingdoms of England and Scotland 'might be united in the person of her deare sonne', and Elizabeth's wish 'that the Religion by her established in England, might be kept and conserved, with the safetie and securitie of the people'. ${ }^{30}$ Camden's recuperation of Mary's status as monarch to reinforce James' position, and its related suppression of the casket materials,

${ }^{28}$ Georgius Conaeus, Vita Mariae Stuartae Scotiae Reginae (Rome, 1624); George Buchanan, Ane Detectioun of the Duinges of Marie Quene of Scottes (1651).

${ }^{29}$ William Camden, The Historie of the Life and Death of Mary Stuart Queene of Scotland (1624), p. 1.

${ }^{30}$ Camden, Historie, pp. 58, 240.

Parergon 29.2 (2012) 
is repeated thirty years later in William Sanderson's dual history of Mary and James, written to reconcile opinions in support of Mary and as a response to texts written in criticism of James. ${ }^{31}$ Both these texts of the early seventeenth century recreate the history of Mary's reign using elements of earlier Catholic defences of Mary's character, and aim to legitimize her son rather than to recreate the immediate religious debates of the sixteenth century. Camden's revised approach to Mary's reign persists throughout the later seventeenth century, to the extent that even a text directed against the Catholic plots of the late 1670 s maintains a representation of Mary as a passive and manipulated figure. A Brief History of the Life of Mary Queen of Scots, which claims to 'open the eyes of Englishmen, against the cursed Plots and Contrivances of the bloud-thirsty Papists', presents a surprising departure from earlier antiCatholic texts. It follows Camden's line on Mary's helplessness in the hands of ambitious Scottish noblemen, and omits any reference to the casket letters and sonnets in its discussion of the trials of $1568 .{ }^{32}$ Its occlusion of the sonnets exemplifies Jacobean rewritings of Mary Stuart's reign: renovating her status as Protestant princess and virtuous mother of James I is incompatible with her status as author, particularly of the casket sonnets.

The restrained English treatment of Mary's reign in the earlier seventeenth century was not followed in France; lacking the pressure exerted by James' reign, two important Catholic pro-Marian defences were circulated, one by the Jesuit Nicolas Caussin and another, posthumously, by Mary's contemporary Pierre de Bourdeille, abbé de Brantôme. With much in common with the defences of late sixteenth-century England, these texts acknowledged Mary's status as author but denied the attribution of the casket sonnets to her. ${ }^{33}$ They became important sources in the later seventeenthcentury English discussion of Mary's reign, which again centred upon the casket material, following its publication in Buchanan's Ane Detectioun in the aftermath of the Revolution of 1688. Ane Detectioun was reprinted in 1689 with the addition of an anonymous preface to the reader which reinforces Buchanan's 1571 representation of Mary as active in the murder of Darnley and in an adulterous relationship with Bothwell, and which seeks to restore Buchanan's authority after his lack of favour under James I. ${ }^{34}$ The reprinting of Ane Detectioun in 1689 reflects a renewed interest in Mary Stuart, coinciding

${ }^{31}$ William Sanderson, A Compleat History of the Lives and Reigns of Mary Queen of Scotland, And of her Son and Successor, James the Sixth, King of Scotland (1656).

${ }^{32}$ M. D., A Brief History of the Life of Mary Queen of Scots (1681), pp. 4-5.

${ }^{33}$ N. Caussin, L'Histoire de l'Incomparable Reyne Marie Stuart (Paris, 1645); Pierre de Bourdeille, Vies des Dames Illustries, 6 vols (Leiden, 1665-66).

${ }^{34}$ George Buchanan, Ane Detectioun of the Duinges of Marie Quene of Scottes (1689), pp. i-ii. 
with the rise of Jacobitism in England from 1688, which sought to restore the Stuart king James II and his heirs to the thrones of England, Scotland and Ireland. The focus of Jacobite political argument upon hereditary right and moral reform had implications both for the currency of Mary Stuart as a political figure and the representations made of her reign. While Mary was a Stuart monarch, and a figure involved in the institution of the hereditary right of later Stuart kings to the English throne through her own connections and the ascendancy of her son James I, her reign was far from an example of political stability and could not be seen to represent the 'golden age' of Stuart rule which Jacobites invoked against the Hanoverians. ${ }^{35}$ Any co-option of Mary Stuart to Jacobite propaganda involved a revisionist stance towards her reign, foregrounding her presentation in Catholic defences as a good and pious woman, rather than as a monarch whose political reign could only be characterized in terms of failure. Again, this translated into a reinforced denial of her authorship of the sonnets, with their vivid depictions of passion within an adulterous relationship.

The difficulty of recruiting Mary Stuart to Jacobitism is reflected in the paucity of texts related to her reign during the heights of Jacobite popularity. From 1656 to 1688 , seven texts concerning Mary Stuart's reign were printed, some of which reflect part of the politics opposing an emergent Jacobitism in their anti-Catholic emphases and celebrations of the peace and happiness of Elizabeth I's Protestant reign. ${ }^{36}$ However, after 1688, Buchanan's Detectioun and a single Jacobite text, Allegations in behalf of the High and Mighty Princess the Lady Mary now Queen of Scots, were the only texts published which concerned Mary Stuart's reign. The Allegations were a reprint of a text from 1565, supporting Mary Stuart's claim to the Scottish crown against the claims made by Katherine Grey. The text is clearly concerned with Jacobite justifications of the hereditary right of the Stuarts to kingship - it was written 'to th'Answer of the Bookes abroade, with th'aduancement of the Lady Mary the French Queen's Issue, and setting foor th of these Cases of Bastardy' - but it also ends with a panegyric to the reign of Elizabeth. Mary Stuart has a role

${ }^{35}$ See Paul Kléber Monod, Jacobitism and the English People, 1688-1788 (Cambridge: Cambridge University Press, 1989).

${ }^{36}$ The seven texts are Sanderson, A Compleat History; a response to Sanderson by Carew Raleigh, Observations upon Some particular Persons ... Compleat History of the Lives and Reignes of Mary, Queen of Scotland, and of Her son James (London, 1656); M. D., A Brief History; two texts concerning Elizabeth's reaction to Mary's execution: Anon., Elizabeth, Queen of England, A Pattern or President for Princes to Rule by, and for Subjects to Obey By (London, 1680) and John Banks, The Island Queens (London, 1684); and two anonymous antiCatholic tracts: Anon., Memoirs of Queen Mary's Days (London, 1679) and Anon., The History of the Life, Bloody Reign and Death of Queen Mary (London, 1682).

Parergon $29.2(2012)$ 
in establishing the hereditary rights of the Stuarts, but Stuart political rule is here associated with Elizabeth, instrumental in passing the English throne to the Stuart line. ${ }^{37}$

The Queen of Scots, at this stage, seems more available to Whig propaganda - the Detectioun, with revised preface, is reprinted four times in the eighteenth century, in $1721,1745,1751$, and 1799 . However, the 1721 edition of Ane Detectioun is followed by a group of four texts published between 1725 and 1727, at the tail end of Jacobitism's height, which seek to provide an authorized history of Mary's reign. This group of texts introduces the persistent convention of identifying the extremes of sixteenth-century religious representations of Mary, and formulates a middle-ground response. Eliza Haywood's Mary Stuart, Queen of Scots introduces itself as 'not a Romance, but a True History' made by identifying a path 'between the two Extremes of Father CAUSSIN'S bigotted Zeal, and the malicious Detraction of BUCHANAN'. ${ }^{38}$ Using Camden as her major source, Haywood argues that the casket letters, invented by Buchanan, are likely to be forgeries as because there were precedents of Mary's handwriting being forged, and there were internal contradictions within the letters that contradicted details of Mary's biography. However, she acknowledges Mary's status as poet by considering Mary's odes upon the death of her first husband, the French king, Francis II. She finds in them 'a certain Sublimity of Sentiment, a Vivacity of Wit, and Strength of Judgement, which few of our Male Poets since can equal'. 39 Samuel Jebb also publishes a history of Mary's reign in 1725, taking the sixteenth-century polarities of response to the letters and presenting them together in the form of a debate. His gathering and assessment of materials primarily establish an 'objective' view of Mary's character, extending the emphasis of seventeenth-century texts upon Mary's character as a means of her recruitment to Jacobean and Jacobite propaganda purposes: personal weakness led to her political failure as sovereign. ${ }^{40}$ Jebb's text forms a model for almost all subsequent considerations of Mary's reign and writing. His collection provides a direct precedent for Anderson's 1727 Collections relating to the History of Mary Queen of Scotland, published not to enter the 'Argument of that Queen's Conduct' but 'for the sake of Truth, the Life and chief Ornament

\footnotetext{
37 Thomas Morgan, Allegations in behalf of the High and Mighty Princess the Lady Mary now Queen of Scots (London, 1690), pp. 3, 19.

${ }^{38}$ Eliza Haywood, Mary Stuart, Queen of Scots (1725), p. iii.

${ }^{39}$ Haywood, Mary Stuart, p. 141; p. 3. Haywood's text is an unacknowledged translation of the anonymous Marie Stuart, Reyne d'Escosse: Nouvelle Historique (Paris, 1675).

${ }^{40}$ Samuel Jebb, The History of the Life and Reign of Mary Queen of Scots, and Dowager of France (1725), p. iii.
} 
of History,' and providing a more pro-Marian set of materials than those given by Jebb. ${ }^{41}$ Unlike Anderson, Jebb supplements his reprinting of sixteenthcentury material with a commentary which analyses Mary's reign in terms of the sixteenth-century debate which he seeks to reconstruct and resolve, re-opening and enlarging the questions surrounding the casket materials. Although Jebb and Anderson, both Nonjurors, maintain a Jacobite focus upon Mary Stuart's character and argue against the authenticity of the casket materials, by reprinting these materials they keep alive her construction as a literary, as well as a political figure, in a departure from her representation in the seventeenth century. ${ }^{42}$

The early eighteenth-century texts of Haywood, Jebb, Anderson, and Simmonds, representing Mary Stuart in terms of agency and accomplishment within the private sphere, reflect three intersecting cultural debates of the late seventeenth and early eighteenth centuries: the human limits of a monarch's authority, the nature of gender, and the relationship between gender and political authority. Public and widespread engagement with questions of sovereign authority involved an interrogation of the monarch's human limits, limits which came to include the gendered body through a focus upon a succession of queens: Mary of Modena, Mary II, and Anne. ${ }^{43}$ Coinciding with Whig reform's recasting of the relationship between gender and authority (although the extent to which this enabled women's enfranchisement has been the subject of considerable debate), women occupied a central and vocal position in political discourse at the turn of the century. Mary Stuart occupies a complex place in these configurations. As a Catholic queen who relinquished her sovereignty, her history could be recruited by Jacobites as paralleling Mary II's relinquishment of her sovereignty and institution of a Protestant line of succession through her marriage to William of Orange. Both the Catholic queen, Mary of Modena, and Mary II were represented in terms of an ideal feminine virtue located in passivity, denial and lack of political ambition. These are the same models used to characterize Mary Stuart as at

${ }^{41}$ James Anderson, Collections relating to the History of Mary Queen of Scotland, 4 vols (Edinburgh, 1727), i, p. iii.

${ }^{42}$ See also Edward Simmonds, The Genuine Letters of Mary Queen of Scots to James Earl of Bothwell (London, 1726). This edition of the casket materials takes a similar approach. Although Simmonds supports the authenticity of the materials, the preface to his text focuses upon Mary's character, and argues that her qualities as 'the most loveliest, but also most accomplish'd and wittiest Woman of her Time' (pp. iii-v), led to her political failure: 'her Youth, Gaiety and good Humour, rendering her often forgetful of her Birth, gave Room for Encroachments to be made on her Prerogative; which afterwards, she found was not in her Power to remove' (pp. 35-36).

${ }^{43}$ For a discussion of women poets' diverse constructions of monarchy in this period, see Carol Barash, EnglishWomen's Poetry, 1649-1714 (Oxford: Clarendon Press, 1996). 
once a model of ideal virtue in private and a political failure in public. But at the same time, her confinement to the private sphere does not extend to her status as writer. References to her 'wit' and the new currency accorded to her writing place Mary Stuart with other late seventeenth-century and early eighteenth-century women writers, such as Aphra Behn and Delarivier Manley, who were praised for their intellect.

The eighteenth century also instituted the first serious examination of Mary Stuart's reign through her writings, beginning with the publication of Walter Goodall's An Examination of the Letters Said to be Written by Mary, Queen of Scots, to James Earl of Bothwell. ${ }^{44}$ Goodall advanced the argument that the French copies of the casket letters had been translated from the Scots versions of the poems printed in Ane Detectioun, and as Scots was not the language in which Mary wrote, she could not have been their author; his thesis was attacked by David Hume and Thomas Robertson, continuing to assert Mary's authorship, but was supported by Tytler, Whitaker, and Crawford. ${ }^{45}$ The debate engaged major historians of the Enlightenment, who frequently reprinted the sonnets from Ane Detectioun, and its terms contributed to Mary's heightened status as a literary figure. However, although the terms used by critics of this period assign Mary Stuart some intellectual, political and literary agency, in practice their analyses of her rule effectively work to confine any constructions of her as a writer to the private sphere. Increasingly, as scholars of the cult of sensibility have shown, eighteenth-century constructions of women confined them to the private and domestic realm of the household and identified them with a set of particularly 'feminine' characteristics: as irrational, emotional, intuitive, and virtuous. ${ }^{46}$ Critical emphasis shifted from early modern women's participation in the public sphere as writers to their role in the household. Margaret Ezell has linked this shift to the construction of a canon of early modern women's writing through the medium of the anthology, arguing that George Ballard's publication of The Memoirs of Several Gentlewomen in 1752 registered an important change in the critical construction of women

${ }^{44}$ Walter Goodall, An Examination of the Letters Said to be Written by Mary, Queen of Scots, to James Earl of Bothwell, 2 vols (Edinburgh, 1754).

${ }^{45}$ David Hume, History of England under the House of Tudor, 2 vols (1759); Thomas Robertson, The History of Mary Queen of Scots, Including an Examination of the Writings which were ascribed to her (Edinburgh, 1793); William Tytler, An Historical and Critical Enquiry into the Evidence against Mary, Queen of Scots (Edinburgh, 1760); John Whitaker, Mary, Queen of Scots Vindicated, 3 vols (1787); Thomas Crawford, The History of Mary Queen of Scots (Edinburgh, 1793).

${ }^{46}$ For accounts of the rise of the cult of sensibility see Janet Todd, Sensibility: An Introduction (London: Methuen, 1986); and Cheryl Turner, Living by the Pen:Women Writers in the Eighteenth Century (London: Routledge, 1992). 
writers. His anthology positions women either in terms of their relationships to male familial members, or in terms of their exemplary personal virtue, and excludes professional women writers such as Aphra Behn.${ }^{47}$ His treatment of Mary Stuart is typical. Although he notes Mary Stuart's accomplishment as a writer, 'valued much by Monsieur Ronsard', and reprints two short poems scratched into windows at Buxton-Well and Fotheringay Castle, Mary Stuart is delineated according to her beauty and accomplishments: 'when she followed most her own inclinations, she would be employed amongst her women in needlework.' Her writing is devalued and, literally, domesticated as an inscription on household windows. ${ }^{48}$

Despite her status as queen, the representations of Mary Stuart throughout the seventeenth century in terms of her personal character and familial status meant that she was especially available to eighteenth-century models valorized by sensibility, especially in terms of her writing. A reprint of the casket sonnets in 1790 opens with a commentary which assesses Mary's reign in terms of the private, domestic approach of earlier commentaries, but with the entire story heightened and dramatized. A comment from Jebb on the provocation of Darnley's behaviour becomes 'He had repaid her tenderness with neglect' and Mary's heart becomes 'the heart of sensibility', driving her to action: she 'felt the insults that were offered her, and too rashly determined to revenge them' ${ }^{49}$ This construction of her character is reinforced through a new translation of the casket sonnets, which is accurately claimed to be 'far from literal'. The sequence is rewritten to emphasise the emotional impact of their actions, inserting Bothwell's name, absent in all the sonnets printed in Ane Detectioun, to dramatize their specific relationship: the first sonnet concludes 'For Bothwell's sake I'd close these eyes in death' ${ }^{50}$ Despite its florid embellishments, this approach allows Mary Stuart's resurrection as a poet and is repeated in other texts of the period. In the 1798 text, The Ruins of Linlithgow, the author's defence of Mary's innocence is placed in the subsidiary notes to a fictitious prosopopoeia of three cantos, a 'simple effusion' which takes an episode of Mary's life as its subject. ${ }^{51}$ Surprisingly, her availability

${ }^{47}$ Margaret J. M. Ezell, WritingWomen's Literary History (Baltimore: Johns Hopkins University Press, 1993), pp. 48-49, 72-74.

${ }^{48}$ George Ballard, ed., Memoirs of Several Ladies of Great Britain (Oxford, 1752), pp. 156-67, 171.

49 Anon., A Sonnet, Supposed to have been written by Mary Queen of Scots, to the Earl of Bothwell; previous to her marriage with that nobleman (London, 1790), pp. ii-iii.

${ }^{50}$ Anon., A Sonnet, Supposed, pp. 11-12.

${ }^{51}$ Joseph D. M'Arthur, The Ruins of Linlithgow, with Selected Notes in Vindication of the Character of Mary, Queen of Scots (Glasgow, 1798), p. iii.

Parergon 29.2 (2012) 
to the cult of sensibility in the eighteenth century means that she is newly configured as a poet, albeit in confined, adapted or simply imaginary terms.

Mary Stuart's availability to models of sensibility continues in the reception history of her texts in the nineteenth century. She is constructed in anthologies as an ideally feminine foil to the politically successful and ambitious Elizabeth I, privileging her qualities as attractive, fallen woman confined to the private sphere through her political failure. Dyce's entry for Elizabeth includes a footnote on Mary Stuart, where the queen of Scots is described as 'that lovely, unfortunate, but surely not guiltless woman', and her poem 'Farewell to France' is reprinted as an example of 'how much her poetical powers were superior to those of Elizabeth'. Mary Stuart is introduced as 'the daughter of debate' in a footnote to Elizabeth's poem 'The doubt of future foes', and Dyce's text draws an implicit comparison between Elizabeth's aggressive defence of her realm - 'Our rusty sword with rest shall first his edge employ, | Shall poll their tops that seek such change, and gape for joy' - and Mary Stuart's nostalgic farewell to France, couched in the language of private emotion. ${ }^{52}$ Similarly, Ritson contrasts Elizabeth's 'savage and malignant cruelty' to Mary's identity as 'that most beautyful and accomplish'd princess', victim of Elizabeth's political ambition to deny her the inheritance of the English throne. ${ }^{53}$ He considers the casket letters and sonnets 'the grossest forgerys', as their content clearly disturbs an idealized construction of Mary; the similar exclusion of the casket sonnets in the early anthologies of Ballard, Ritson, and Dyce is continued in later anthologies,

52 Alexander Dyce, ed., Specimens of British Poetesses (London: T. Rodd, 1825), p. 13.

${ }^{53}$ Joseph Ritson, Observations on The Three First Volumes of the History of English Poetry (London, 1782), p. 337. This theme of a personally motivated rivalry between Elizabeth and Mary is also current in nineteenth-century histories of Mary's reign, where Mary's innocence and vulnerability is constructed as a foil for Elizabeth's jealousy and treachery. Chalmers represents Elizabeth as 'torn, by the uneasy passions of envy, hatred and jealousy' in his 1818 Life of Mary; in 1826, an anonymous text defending 'the virtuous, high-principled, and innocent Queen of Scots' sought also to paint the 'jealousy, envy, ambition, perfidy, and iniquitous intrigues of Queen Elizabeth ... in their true colours'. The same approach is repeated in at least five texts in the first half of the nineteenth century: see George Chalmers, The Life of Mary, Queen of Scots; Drawn from the State Papers, 2 vols (London: John Murray, 1818), I, 329; Anon., Mary Queen of Scots: Her Persecutions, Sufferings, and Trials from her Birth till her Death (Glasgow: W. R. McPhun, 1826), p. 252; Henry Glassford Bell, Life of Mary, Queen of Scots, 2 vols (Edinburgh: Constable and Co., 1828), I, 178, 188; Anon., Life of Mary, Queen of Scots (Elgin: J. Grant, 1828), p. 182; Mme J. G. B., Histoire de Marie Stuart, Reine d'Écosse et de France (Limoges: Chez Barbou Frères, 1842), pp. 118, 258; L. Stanhope F. Buckingham, Memoirs of Mary Stuart, Queen of Scotland, 2 vols (London: Richard Bentley, 1844), I, 333-34; Alexander M'Neel-Caird, Mary Stuart: Her Guilt or Innocence (Edinburgh: Adam and Charles Black, 1866), p. 221; J. B. Rose and E. M. Rose, A Tribute to the Memory of Mary Queen of Scots (London: William Clowes and Sons, 1868), p. 12. 
despite a renewed interest in the casket sonnets in other studies of Mary Stuart in the nineteenth century.

The nineteenth-century historical and literary identity of Mary Stuart is characterized by a consistent increase of texts and genres: she becomes the focus of interest for different causes, each using an aspect of her life as material to illustrate its concerns. Early in the nineteenth century, literary historians, to use Robertson's expression, 'entered the field, as if it never almost, had been trodden before'.${ }^{54}$ Each claimed to be a bibliographical originator, and a small industry arose reprinting or claiming access to previously unknown documents relating to the trial, even claiming Mary Stuart's writing of the casket material as exclusive discoveries. ${ }^{55}$ An increasing number of Scottish imprints of histories or documents relating to her life indicate her growing importance to the revisionist histories prompted by Scottish nationalism Bell's 1828 Life of Mary capitalized upon the concentration on her character by marking the period as 'a time when national and individual character were alike strongly marked'. ${ }^{56}$ She also becomes a renewed point of focus for debates surrounding the nature of women and their capacities in public and personal contexts. Mary's position as a woman ruler, coupled with her history of representation as a domesticated figure whose private character had repeatedly come under textual examination, meant that she was uniquely available for scrutiny in both the public and private realms. Hugh Campbell's edition of the letters in 1824 uses Mary Stuart as an example of the capacity of women for the unscrupulous pursuit of political power, a position which led to a number of chivalric defences of female innocence and sovereignty. ${ }^{57}$ The polarity of these positions reflects wider cultural debates concerning

54 Thomas Robertson, The History of Mary Queen of Scots (Edinburgh, 1793), p. x.

${ }^{55}$ Examples of this movement include: Anon., Collections Relative to the Funerals of Mary Queen of Scots (Edinburgh: W. and D. Laing, 1822); W. Stevenson Fitch, ed., Maitland's Narrative of the Principal Acts of the Regency, During the Minority; and Other Papers Relating to the History of Mary, Queen of Scotland ([n. p.], 1833); Robert Pitcairn, ed., Historical Memoirs of the Reign of Mary Queen of Scots, and a Portion of the Reign of King James the Sixth (Edinburgh: Abbotsford Club, 1836); Anon., Papers Relating to Mary Queen of Scots (London: Philobiblon Society, 1872-76).

${ }^{56}$ Bell, Life of Mary, I, p. vii.

${ }^{57}$ Hugh Campbell, The Love Letters of Mary Queen of Scots to James Earl of Bothwell with her Love Sonnets and Marriage Contracts (London: Longman, 1824), p. 6: 'To such then as think it not only possible but probable that such a woman could be so infatuated with a man as to urge him to sue for and obtain a divorce from his lawful wife, and afterwards to force that wretched dupe to her lusts to destroy her own husband and assume his rights, I think I may fearlessly appeal for approbation of my views.' For a typical defence, see George Chalmers, A Detection of the Love-Letters Lately Attributed in Hugh Campbell'sWork to Mary Queen of Scots (London: John Murray, 1825), pp. 1-4. 
the nature of women. Campbell's theories of agency are related to Mary Wollstonecraft's argument against the natural inferiority of women. Rather, she suggests that in both genders, virtue is not inherent but a gift to both sexes from God, gained in the individual through the exercise of reason and understanding. ${ }^{58}$ The other side of this debate, promoting an inherent female virtue, makes these negative actions impossible for a woman and arises from the conservative view, dominant in the 1790s and early nineteenth century, that women possess a latent moral superiority. In the religious revivalism of the period, qualities seen as traditionally feminine such as humility, submission, and self-denial were also increasingly seen to fit the norms of a new, dynamic Christianity, and femininity became something to be exalted and defended in the name of virtue. ${ }^{59}$

The terms of this debate sharpen the discussion of the authenticity of the casket sonnets: they are both newly constructed as within the capacities of a woman writer, and vigorously identified as exclusively male writing. ${ }^{60}$ This shift wrests the discussion of the sonnets from criticism dividing along religious lines to a limited consideration of Mary Stuart as a writer. ${ }^{61}$ Two collections of her letters were published in French, and both Agnes Strickland and William Turnbull translated the collection edited by Labanoff into English. ${ }^{62}$ In 1873, Julian Sharman's edition of The Poems of Mary Queen of Scots asserts that 'it is as a poet and an encourager of verse-writers that she may appear to many in altogether a new character'. This consideration of the sonnets is still marked by the pervasive mid-eighteenth-century ideology of the feminine. Sharman

${ }^{58}$ Mary Wollstonecraft, AVindication of the Rights of Women, in Wollstonecraft, PoliticalWritings, intro. Janet M. Todd (Oxford: Oxford University Press, 1994).

${ }^{59}$ For a discussion of this conservative approach, see Jane Rendall, The Origins of Modern Feminism: Women in Britain, France and the United States 1780-1860 (Basingstoke: Macmillan, 1985), pp. 73-107.

${ }^{60}$ For identification as male writing, see Chalmers, A Detection, p. 89; and John Hosack, Mary Queen of Scots and her Accusers (Edinburgh: William Blackwood and Sons, 1869), p. 199. The contemporary denunciation by both Ronsard and Brantôme on the basis of the sonnets' style rather than their content is much repeated in this period; see for example M'Neel-Caird, Mary Stuart, p. 178.

${ }^{61}$ Campbell, The Love Letters, p. 336. Campbell finds them 'inelegant' but argues that no one can be 'equal in his productions, especially one whose style is so little formed as Mary's must be supposed to be', and that the danger and criminality surrounding the sonnets' composition would 'leave little tranquillity of mind for elegant poetical compositions'.

${ }^{62}$ Alexandre Labanoff, Lettres Inédites de Marie Stuart (Paris: Chez Merlin, Libraire, 1839) and Lettres, Instructions et Memoires de Marie Stuart, 7 vols (London: Charles Dolman, 1844); Alexandre Teulet, Papiers D'État, 3 vols (Paris: Plon Frères, 1852-60) and Lettres de Marie Stuart (Paris: Librairie de Firmin Didot Frères, 1859); Agnes Strickland, Letters of Mary Queen of Scots, 2 vols (London: Henry Colburn, 1842); William Turnbull, Letters of Mary Stuart, Queen of Scotland (London: Charles Dolman, 1845). 
contends that the verses do not really stand up to literary analysis, and their main interest again is in illustrating Mary's character, in their 'connection with the history of the unfortunate sovereign whose inner life they would seem to illustrate'. All her pieces are seen as personal and emotional, 'produced on occasions of extraordinary grief or emotion' ${ }^{63}$ However, Sharman's text marks a significant change in the reception of Mary Stuart. She moves from literary and historical object, spoken for and constructed in the terms of the prevailing model of gender, to a tangible poetic voice, her collected poetic verse available for the first time in one edition.

\section{III}

The early twentieth-century response to Mary Stuart builds upon this emergence of Mary's discrete poetic voice from the casket letter controversy. Although some texts continue to present the materials surrounding the casket letters and sonnets, and others continue to seek to introduce new material into the debate, there is a movement away from the endless reworking of earlier arguments. Early in the century, quarter-centenary anniversaries for Buchanan and Knox directed attention towards that period of history, with an attendant interest in the figure of Mary Stuart. ${ }^{64}$ Where the casket letters are discussed in this historical context, there is often no mention of the sonnets, and a sub-genre of popular material taking the history of Mary Stuart as its subject leaves out the casket debate altogether for want of space, and because of the complexity of the material. ${ }^{65}$ However, there is an increased and consistent interest in Mary Stuart as a writer. ${ }^{66}$ Methven released a text

${ }^{63}$ Julian Sharman, ed., The Poems of Mary Queen of Scots (London: Basil Montagu Pickering, 1873), sigs $\mathrm{A} 1^{\mathrm{v}}-\mathrm{A} 4^{\mathrm{v}}$.

${ }^{64}$ Andrew Lang, The Mystery of Mary Stuart (London: Longmans, Green, 1901), p. i. Lang justifies his interest in Mary Stuart with 'Wells were sunk, as it were, deep into human personality, and the inner characteristics of the age leaped upwards into the light'; however, Martin Hume, The Love Affairs of Mary, Queen of Scots: A Political History (London: Eveleigh Nash, 1903), despite its unpromising title, takes issue with this tradition by arguing that the focus on principal characters throws the other events and influences of the period out of perspective (pp. v-vii).

${ }^{65}$ Popular texts bypassing the casket letter debate include pamphlets such as Rev. Canon Odom, Mary Stuart, Queen of Scots (Sheffield: E. Weston and Sons, 1926); Mrs MaxwellScott, Mary Queen of Scots (London and Glasgow: Catholic Truth Society, 1930); and romances such as A. H. Millar, The Romance of Mary Queen of Scots (Dundee: Valentine and Sons, 1927).

${ }^{66}$ There is also an increased interest in Stuart as a ruler. The rhetoric of the preface to Hume, The Love Affairs, p. vii, claims the text's purpose to be an examination of 'the reasons for her disastrous political failure' previously obscured by critical interest in her vice or virtue. The same interest is evident in Florence A. MacCun, Mary Stuart (London: 
in 1913 of excerpts from her 'many letters and noble sayings', arranged in the form of a yearbook. His source is the material that Mary Stuart used to present a favourable case of her circumstances, and his selection serves to further sanitize her literary presence. His text emphasizes first of all her piety, and secondly her maternal qualities regarding James: 'that he was never absent from her thoughts is proved by her constant letters ... begging for news of him and full of anxiety concerning his welfare.' Methven's preface indicates his interest in representing her public qualities of nobility, love of justice and truth, courage and dignity, but balanced by the 'things that bring us more in touch with the Woman than the Queen' - her interest in the domestic environment of servants, pets, and needlework. Aimed at the 'casual reader', the text seeks to present in Mary Stuart's own words an account of her life; it claims further that a perusal of the materials in the casket debate leads the reader to 'know that Mary, Queen of Scots, was innocent'. ${ }^{67}$ The reader knows her innocence not by examination of a set of materials that also possibly suggest Mary Stuart's guilt, but through a form of sympathy, an intuitive understanding reinforced by Mary Stuart's writing. This approach is predicated upon a placing of her writing in a familiar personal context - as private documents disconnected with any public function of petitioning for political support, or communicating with supporters. This intuitive faculty is also used in an earlier text concentrating on Mary Stuart's literary output by P. Stewart-Mackenzie Arbuthnot, Queen Mary's Book. She moves away from the nineteenth-century detailed analyses surrounding attribution to argue that merely reading the casket letters enables one to 'almost know which sentences might conceivably have been written by Mary'. ${ }^{68}$ Arbuthnot's separation of the sonnets from the letters is continued in Clifford Bax's The Silver Casket, a collection of the love letters and poems attributed to Mary Stuart, which strongly argues for their authenticity. ${ }^{69}$ By the mid-twentieth century, therefore, the possibility of the separation of the sonnets from the casket material was becoming more entrenched, as Mary Stuart's identity as a writer began to exist alongside her status as historical character. ${ }^{70}$ Although

Methuen, 1905), which opens with the proposal that 'any one wishing to know what the direct influence of women would be in the governing of nations has only to make a study of Western Europe in the latter half of the sixteenth century' (p. 1).

${ }^{67}$ A. A. Methven, ed., A Year Book of Mary Queen of Scots (London: T. N. Foulis, 1913), pp. vii-xi.

${ }^{68}$ P. Stewart-McKenzie Arbuthnot, Queen Mary’s Book (London: George Bell, 1907), p. 157.

${ }^{69}$ Clifford Bax, The Silver Casket: Being Love-Letters and Love-Poems Attributed to Mary Stuart, Queen of Scots (London: Home and Van Thal, 1946), pp. 11-18.

${ }^{70}$ This is not to suggest, however, that the long tradition of considering the sonnets at the margin of the casket letters, and in a primarily historical context, is easily escaped. 
seen now as a sovereign who was also an author, the way in which that authorship was conceived continued to be restricted by assumptions about women writers until well into the twentieth century.

This limitation extends to the gynocritical feminist accounts that formed the first critical context for current approaches to the casket sonnets. In this tradition, Betty Travitsky's treatment of Mary Stuart in The Paradise ofWomen forms a departure from the problematic history of reception of the casket materials by making an uncomplicated attribution and reprinting the casket sonnets as her work. The attribution, while seeking to move away from an assessment of her work solely as part of an interest in her political, religious, or moral attitudes, again recycles some of the materials of an earlier historical criticism. The sonnets are seen as unproblematically autobiographical, indicating that 'she was genuinely and deeply in love with Bothwell', and follow Arbuthnot's evidence for attribution. This is grounded on subjective opinion - 'I do not feel the same conviction that the Mary Stuart touch is absent as I do in the case of most of the letters' - but also on a correspondence in metre, 'the play on the word subject', and the standardized use for the period of $i$ not $j, u$ not $v$ in the centre of words which is identified as particular to Mary Stuart's style rather than to sixteenth-century print conventions. Travitsky supplements this analysis by linking 'the subject matter and obvious emotion of the poet' to the style of Mary Stuart's usual poetic model, Ronsard, and by identifying similarities to the poetry of du Bellay. ${ }^{71}$ This evidence is seen as sufficient grounds for the attribution, taken up in Robin Bell's 1992 edition of the poems of Mary, Queen of Scots, Bittersweet Within my Heart, which identifies a 'real' Mary, Queen of Scots who 'has been allowed to disappear under the weight of words written about her'. The text's purpose 'is to let her speak up for herself in her own words', constructing the poetic text as transparent conduit for the woman author's subjectivity:

Enough has been said to show the plausibility of Mary's authorship of the sonnets. It is time to consider the poems themselves and to appreciate the

Many twentieth-century historical texts dealing with Mary's reign continue to dismiss the sonnets: see Eric Linklater, Mary Queen of Scots (London: Paul Davies, 1933), p. 126 : 'a series of pseudo-sonnets written in French'; N. Brysson Morrison, Mary Queen of Scots (London: Vista, 1960), p. 168: 'The sonnets are rather unpleasant love-poems written in French'; George Malcolm Thomson, The Crime of Mary Stuart (London: Hutchinson, 1967), p. 149: 'a long (bad) poem'. Others preface detailed consideration of the sonnets with a negative judgement of their literary value: see, for instance, M. H. Armstrong Davison, The Casket Letters: A Solution to the Mystery of Mary Queen of Scots and the Murder of Lord Darnley (London: Vision, 1956), p. 206.

${ }^{71}$ Betty Travitsky, The Paradise of Women: Writings by Englishwomen of the Renaissance (Westport, CT: Greenwood, 1982), pp. 187-91. 
emotion animating them and reaching across the centuries to convince the reader of its truth. ${ }^{72}$

Bell's edition not only simplifies the relations between author and speaker and neglects the complex and unresolved problems of attribution that attend the sequence, it places a modern English translation next to the French originals and excludes the Scots parallel text published in Ane Detectioun, Bell's source, without acknowledging variants or substitution. Unsurprisingly, it also overwhelmingly frames these poems as private, emotional, and uncontrolled: 'Sometimes Mary could not think of a good ending to a poem ... Events moved so fast in the early summer of 1560 that she never had the time or peace of mind to revise what she had written. ${ }^{73}$

It seems extraordinary that Bell's popular collection is the best modern edition available for the poetry of one of the period's most important literary and political figures. As Anna Riehl points out, recent scholarship has 'produced a consensus about Elizabeth's rhetorical dexterity', yet has only just begun to approach isolated letters and poems within Mary Stuart's oeuvre. ${ }^{74}$ She remains peculiarly confined to the private sphere despite her public role, and I would suggest that this marginalization of her writing draws upon the complex reading history of her texts. While this history is occluded, the assumptions drawn from it appear natural: of course Elizabeth is a more significant and polished public writer than her cousin. Even the most sophisticated analyses of the casket sonnets in the last decade reproduce elements of these earlier readings. Sarah Dunnigan's complex and historically nuanced reading positions the poems as 'significant literary as well as cultural documents', but considers them in relation to 'the image of Mary' formed in opposition to that of Elizabeth: 'Unlike Elizabeth's carefully managed eroticisation (a desirability that never tolerated any breach), these sonnets seemingly enact the realisation of desire for the sovereign. ${ }^{75}$ The poems enact desire, by eliding erotic and sovereign selves, in ways that associate Mary with excess and disorder and Elizabeth with control and inviolability. For Dunnigan, these poems are ultimately powerful but uncontrolled, 'confessions of contradictory, violent and intense erotic desires'. Peter Herman's more recent analysis reads the sonnets in terms of their 'manipulation of early modern gender roles', both inverting male/female agency through the

${ }^{72}$ Robin Bell, ed. and trans., Bittersweet Within my Heart: The Collected Poems of Mary Queen of Scots (London: Pavilion, 1992), p. 8.

${ }^{73}$ Bell, ed., Bittersweet Within my Heart, p. 35.

${ }^{74}$ Anna Riehl, The Face of Queenship: Early Modern Representations of Elizabeth I (Basingstoke: Palgrave Macmillan, 2010), p. 27.

${ }^{75}$ Dunnigan, Eros and Poetry, pp. 20, 29. 
assumption of the authorial subject position, where 'women act and men respond', and enacting a contradictory 'self-subjection', where erotic subjectivity is privileged over political identity. ${ }^{76}$ The contradiction he finds is that the speaker in these sonnets 'uses her position as monarch to undermine her position as monarch' ${ }^{77}$ While these oppositions coexist in his chapter on Mary Stuart, they produce a familiar narrative of rhetorical instability and contradiction, especially in contrast to Herman's following chapter on Elizabeth's poetry which stresses, again, her increasing textual dexterity and rhetorical control as an author over her lifetime. There is no doubt that the content of the casket sonnets contributes to such analyses, outlining the female sovereign subject's personal and political submission to her lover. But when coupled with a history of reading these sonnets as private effusions by a figure associated with disorder and excess, such analyses become over determined and exclude other heuristic possibilities. While the casket sonnets might be newly seen as examples of rhetorical complexity, particularly in their generic mixing of popular complaint and Petrarchism, my purpose here is not simply to reassign the cultural capital associated with authorship from Elizabeth to Mary. Rather, I am interested in understanding why certain readings are repeated or reformed, and how histories of redaction and reception might delimit critical possibilities surrounding early modern women and authorship.

For diverse political, historical, and bibliographical reasons, Mary Stuart's status as author, particularly in relation to the casket sonnets, has been either denied or translated into versions of feminine textuality with limited appeal for current scholars of early modern women's writing. Reading Mary Stuart's writing with its reception in mind, however, would provide many challenges to the field itself. It would force a reassessment of hidden canonical biases at work in the field, as well as a new conception of the diverse ways in which female sovereigns deployed texts. What would it mean to consider Mary Stuart, rather than Elizabeth I, as the most widely read example of a writing queen in sixteenth-century England? How would our concepts of rhetorical mastery, feminine literary agency, and women's circulation of their texts shift if the existing binary of queens as authors were dismantled? The history of the casket sonnets' reception is available because of the persistent historical interest in Mary Stuart, and provides a unique perspective on the ways in which early modern women's authorship is constructed and valued according to specific historical, religious, and geopolitical formations, as well as the extent to which the cultural capital of authorship depends on earlier readings. Much recent work in the field of early modern studies has

${ }^{76}$ Herman, Royal Poetrie, pp. 86, 93.

${ }^{77}$ Herman, p. 98. 
centred on rethinking the institution of authorship in terms of sociality and collaboration. Reception history, the fragmentary record of communities of readers over time that cumulatively produce authorship, is an equally crucial but overlooked term in this process, especially for the field of early modern women's writing.

The University of Newcastle, Australia 
